EPiC Series in Engineering
Volume 3, 2018, Pages 1-9
HIC 2018. 13th International
Conference on Hydroinformatics

\title{
Improving River Flow Simulation Using a Coupled Surface-Groundwater Model for Integrated Water Resources Management
}

\author{
Salam Abbas ${ }^{1}$, Yunqing Xuan ${ }^{1 *}$ and Ryan Bailey ${ }^{2}$ \\ ${ }^{1}$ College of Engineering, Swansea University Bay Campus, Swansea SA1 8EN, U.K. \\ ${ }^{2}$ Dept. of Civil and Environmental Engineering, Colorado State University, CO 80523, USA \\ y.xuandswansea.ac.uk
}

\begin{abstract}
Accurate simulation of both land surface and groundwater hydrologic processes in river catchments is an important step for integrated water resources management, particularly for catchments where both surface water and groundwater resources are used conjunctively. In this paper, we present a study on a complex river catchment - the Dee River catchment in the United Kingdom using a coupled land surface model (SWAT) and groundwater model (MODFLOW) to improve the performances of both models otherwise used separately, hence serving the IWRM goals of optimizing conjunctive use of surface and groundwater. The model can also be used to evaluate the sensitivity of stream flows to changing climate, groundwater extraction, and land use alternations. Preliminary results show that the coupled model can improve river flow simulation especially baseflow simulation while significantly improving the overall water balance model simulations during periods of low flow.
\end{abstract}

\section{Overview}

Integrated Water Resources Management (IWRM) at the catchment level relies heavily on the use of computer model simulations that capture the underlying hydrological processes and surface water/groundwater allocations. Models often used for such as assessment include SWAT [1] and MODFLOW [2]. Previous studies [3, 4] have shown that both models can perform very well in many applications where surface water and groundwater remain as their focus, respectively.

However, for more complex IWRM scenarios where both surface and groundwater abstractions are substantially utilised, coupling of traditionally surface water orientated hydrological models such as SWAT, with a dedicated groundwater model such as MODFLOW can aid in hydrologic

${ }^{*}$ Corresponding author. 
Improving River Flow Simulation Using a Coupled Surface-Groundwater Model for ... S. Abbas et al.

assessment and therefore has become a focal research area in recent years. More recently, progress has been made $[5,6]$ to develop a series of tools that can conveniently couple SWAT with MODFLOW on a daily time step. Many applications have also been reported.

Among the hydrological system response variables involved in IWRM, accurately simulating baseflow can be a key for providing a better estimation of groundwater recharge, which aids in sustainable water resources management. Baseflow is a component of streamflow that reacts slowly to precipitation and is typically associated with water discharged from groundwater storage [7]. Under low-flow conditions, the detailed information of baseflow is useful for the evaluation of streamflow forecasting, allocating water resources and design of hydropower plants [8]. Accurately simulating when, where, and how much streamflow can be attributed to groundwater discharge is therefore practically significant [9].

The SWAT model uses a conceptual one-reservoir (shallow aquifer storage) method to simulate baseflow [9]. It divides groundwater component into two aquifer systems [10]:

- Shallow aquifer that contributes baseflow to streams within the watershed; and

- Deep aquifer that contributes baseflow to streams outside the watershed and can be considered lost from the system.

Many researchers have reported that SWAT performs poorly in estimating baseflow $[9,11,12$, and 13]. Previous studies also have been linked SWAT and MODFLOW codes [5, 14 and 15]. Typical model integration includes using SWAT-calculated soil deep percolation as recharge for MODFLOW and using MODFLOW-simulated groundwater-surface water interaction (i.e. groundwater discharge to stream; stream seepage to aquifer) as input for SWAT [6].

In this study, our focus is to evaluate the overall water balance and baseflow in a complex river catchment in the United Kingdom, based on a well-performing SWAT model that simulates high and peak flow satisfactorily throughout the catchment. This paper demonstrates the method developed by [6] of linking SWAT and MODFLOW for the Dee River catchment and preliminary results and analysis. Finally, a conclusion is drawn with recommendation for further studies.

\section{Materials and Methods}

\subsection{Study area}

The Dee River originates from the mountainous area of Snowdonia National Park in North Wales in the UK. The main stem of the river is $113 \mathrm{~km}$ with a catchment area of $2,215 \mathrm{~km}^{2}$ (Fig. 1). The river flows eastward to the Wales-England border at the City of Chester before discharging into the Irish Sea at Liverpool Bay. There are four reservoirs in the upper region of the catchment for water supply and flood control. In the lower region to the east, both surface water abstraction and groundwater abstractions are operated under public water supply (PWS) license. 
Improving River Flow Simulation Using a Coupled Surface-Groundwater Model for ... S. Abbas et al.

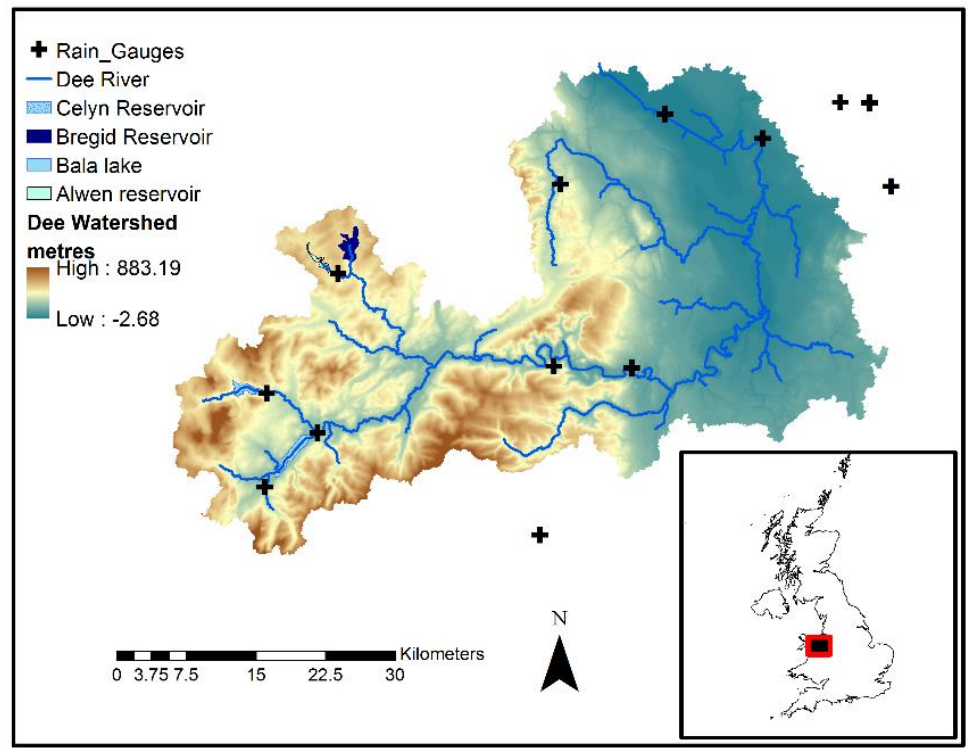

Figure 1: The Location of the Dee River catchment

Elevation data from a DEM, daily precipitation, streamflow and reservoir releases were collected for building a SWAT model for the catchment. Geologic data collected from the British Geological Survey were used to provide aquifer thickness and initial spatially-varying aquifer properties for the MODFLOW model. The locations of the river gauge stations and groundwater monitoring station are shown in Fig. 2.

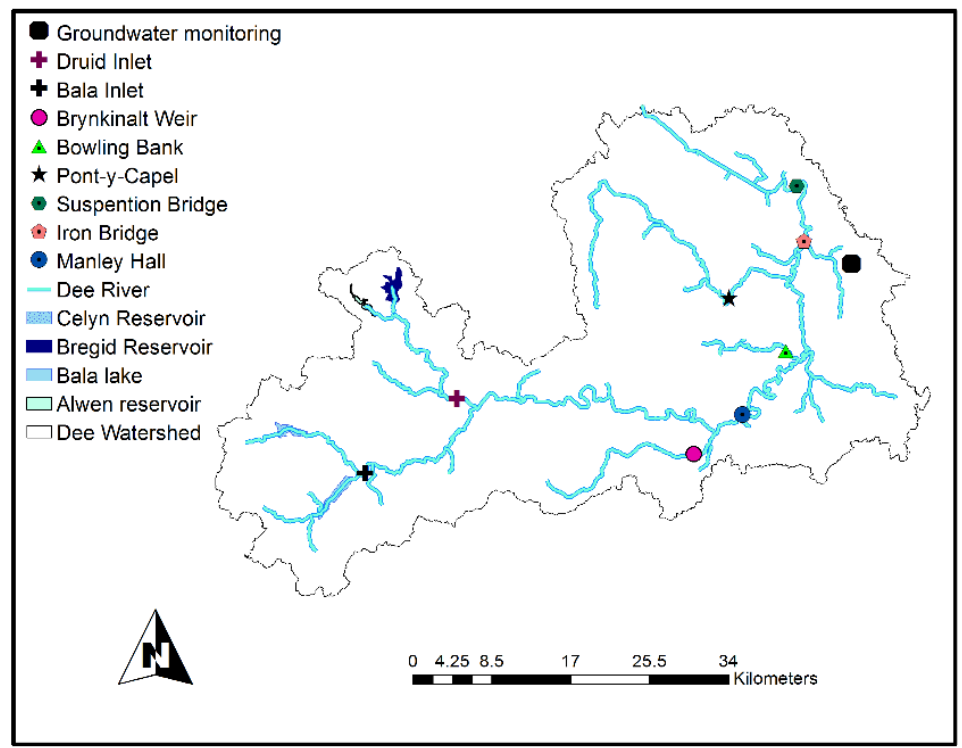

Figure 2: The locations of flow gauges and groundwater monitoring station 
Improving River Flow Simulation Using a Coupled Surface-Groundwater Model for ... S. Abbas et al.

\subsection{SWAT model}

The Soil and Water Assessment Tool SWAT [1] is a continuous, basin scale, distributed parameter watershed model emphasising surface processes. It is developed by the US Department Agricultural Research Service to simulate water flow, nutrient mass transport and sediment mass transport at the watershed scale. In SWAT, watershed is divided into sub-basins which are then further split into multiple unique combinations Hydrological Response Units (HRUs) of land use, soil and slope for which detailed water, nutrient and sediment mass balance calculations are performed. These HRUs may or may not be spatially contiguous with sub-basins. Calculations in SWAT are performed at each HRU and then scaled up to the sub-basin outlet by the percent of area of the HRU within the subbasin [5].

Furthermore, water, nutrient and sediment output from each HRU are routed directly to the subbasin stream for routing through stream network. For groundwater-surface water interactions, therefore, system response variables such as groundwater discharge to streams or river seepage to the aquifer are available only at the sub-basin level [5]. An indicator of groundwater storage such as groundwater table are not geographically located owing to simplistic representation of sub-surface process, thereby limiting model use in watersheds wherein groundwater discharge contributes significantly to stream flow [16].

\subsection{MODFLOW}

MODFLOW [2] is a three-dimensional, physically based, distributed finite difference groundwater model for variably saturated porous media. A recent addition to MODFLOW is a Newton-based solver algorithm (MODFLOW-NWT) that better satisfies the complex non-linear drying and rewetting of grid cells in an unconfined groundwater system [2]. Available processes to be simulated in MODFLOW include: groundwater recharge, vadose zone percolation, evapotranspiration, pumping, discharge to sub-surface drains, and river-aquifer interactions [5]. However, model application is limited to investigating management and climate effects on groundwater and surface-groundwater interaction as MODFLOW does not simulate surface processes such as land-atmospheric interactions, infiltration and surface runoff, nutrient cycling and transport, plant growth and the impact of management practice on agricultural systems.

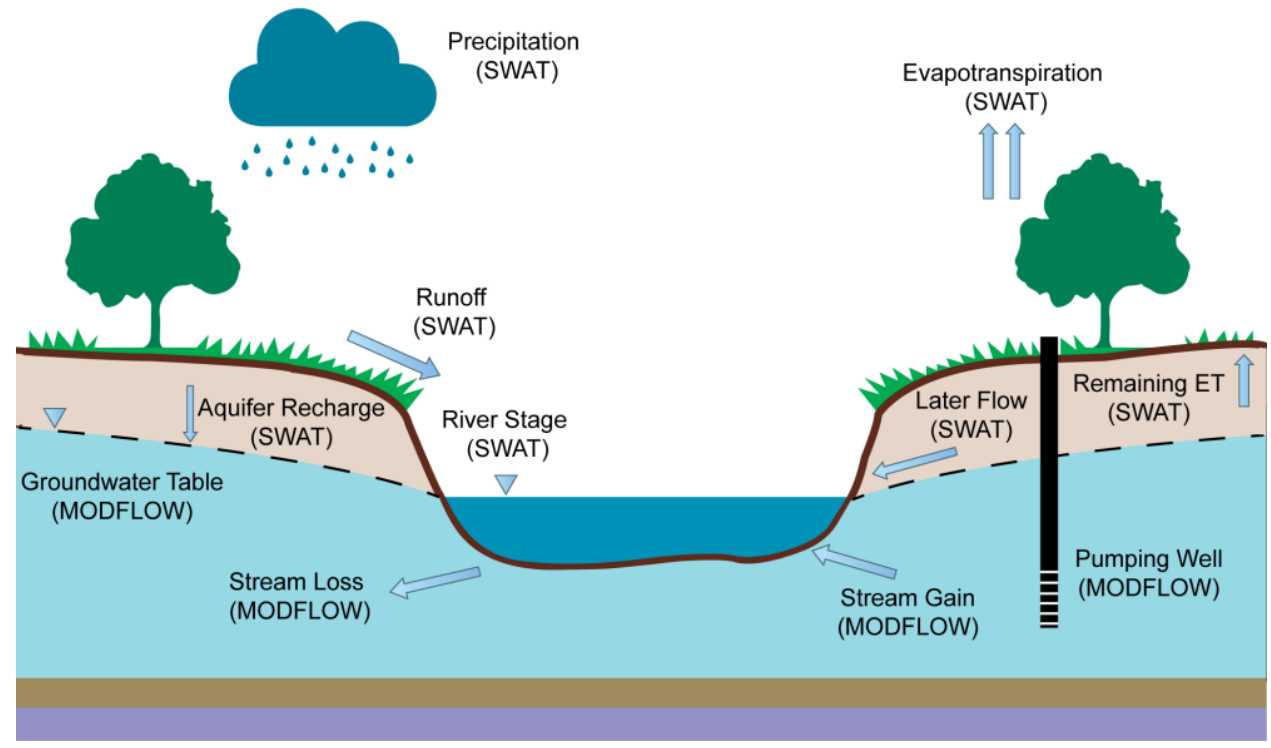

Figure 3: Schematic representation of SWAT-MODFLOW model 
Improving River Flow Simulation Using a Coupled Surface-Groundwater Model for ... S. Abbas et al.

\subsection{SWAT-MODFLOW model}

The calibrated daily SWAT model was used to be integrated with the MODFLOW. The simulation period of 1992-2003 with a 3-years warm-up period to make hydrological cycle fully operational (1995-2000 calibration period) and the rest for the validation. Six streamflow gauge station will be employed to test the performance of the simulated river flow of both SWAT model and coupled SWAT-MODFLOW. In this study, we used the coupled SWAT-MODFLOW framework [6] that was developed to combine the updated SWAT 2012 (Revision 627) model with MODFLOWNWT. In this framework, SWAT simulates land surfaces processes, crop growth, in-stream processes and soil zone processes, whereas MODFLOW-NWT simulates three-dimensional groundwater flow and all major groundwater sources and sinks (e.g. recharge, pumping, discharge to tile drains and interaction with stream networks). Both modelling codes are combined into a single FORTRAN code that is compiled and run as a single executable file. Figure 3 shows the schematic representation of SWAT-MODFLOW model.

The essential process of linking SWAT and MODFLOW models is to pass HRU-calculated deep percolation (i.e. water that exits the bottom of the soil profile) as recharge to the grid cells of MODFLOW, and then pass MODFLOW-calculated groundwater-surface water fluxes to the stream channels of SWAT [5]. With this method, SWAT computes the volume of overland flow and soil lateral flow to streams; whereas MODFLOW calculates the volume of groundwater discharge to streams, and then SWAT routes the water through the channel network of the watershed. Groundwater- surface water interaction is simulated using the River Package of MODFLOW, which applies Darcy's law to calculate the volumetric flow of water through the cross sectional flow area between the aquifer and stream channel.

Data are passed between the models using 'mapping' subroutines that relate HRUs to MODFLOW grid cells and MODFLOW river cells to SWAT stream channels [5]. The main elements of this mapping scheme are: HRUs; Disaggregated HRUs (DHRUs), which divide each original HRU into individual, contiguous areas within a sub-basin allow HRU calculations to be geo-located; MODFLOW grid cells; MODFLOW River cells; and SWAT stream channels. The calculated deep percolation (i.e. recharge) for HRUs are first mapped to each individual DHRU, and then mapped to each MODFLOW grid cell according to the percent of area of the DHRU contained within the grid cell for use by the recharge package. SWAT-calculated channel depth from each sub-basin is mapped to the group of River cells within the sub-basin for use by the River package [5].

MODFLOW then computes groundwater hydraulic head and groundwater-surface water interactions, which are passed to SWAT. Groundwater discharge volumes, computed on cell by cell basis within MODFLOW, are summed and added to in-stream flow for each SWAT sub-basin. SWAT then completes the stream routing calculations for the day, with the daily loop continuing until the end of the simulation. Within this scheme, MODFLOW is called as a subroutine within the SWAT framework, providing a single compiled FORTRAN code [5].

\subsection{Baseflow separation}

We have utilised the baseflow separation method suggest by Lyne and Hollick [17]. For detailed information, readers can refer to $[17,18]$. Baseflow separation is conducted using the $\mathrm{R}$ statistical package 'EcoHydRology' [19].

\section{Results and discussion}

Table 1 shows the performance of the river flow calibration of the two models, e.g., the standalone calibrated SWAT model and the coupled SWAT-MODFLOW model. Several indices are used 
Improving River Flow Simulation Using a Coupled Surface-Groundwater Model for ... S. Abbas et al.

including Nash-Sutcliffe Coefficient (NSE), $\mathrm{R}^{2}$ and percentage of bias (PBAIS) to measure the deviation of simulations from the observations at the chosen gauge stations. A slight decrease of NSE and $\mathrm{R}^{2}$ can be seen across all gauge stations except two stations where groundwater is dominant. In terms of PBIAS, the coupled model performs better or similar except that of the gauge Brynkinalt Weir.

\begin{tabular}{l|c|c|c|c|c|r}
\hline \multirow{2}{*}{ Station } & \multicolumn{3}{|c|}{ SWAT } & \multicolumn{3}{|c}{ SWAT-MODFLOW } \\
\cline { 2 - 7 } & NSE & $\mathbf{R}^{\mathbf{2}}$ & PBIA & NSE & $\mathbf{R}^{\mathbf{2}}$ & PBIA \\
\hline Manley Hall & 0.94 & 0.95 & -5.80 & 0.90 & 0.95 & 14.50 \\
\hline Chester & 0.82 & 0.82 & -6.20 & 0.76 & 0.79 & 11.40 \\
\hline Suspension & 0.78 & 0.80 & -10.20 & 0.83 & 0.91 & 16.10 \\
\hline Pont-y-Capel & 0.80 & 0.82 & -14.70 & 0.77 & 0.78 & 8.80 \\
\hline Bowling Bank & 0.66 & 0.71 & -25.10 & 0.67 & 0.67 & -3.00 \\
\hline Brynkinalt Weir & 0.66 & 0.70 & 10.90 & 0.57 & 0.64 & 27.00 \\
\hline
\end{tabular}

Table 1: The calibrated river flow of the standalone SWAT model and the coupled SWAT-MODFLOW model for the period of 1995-2000

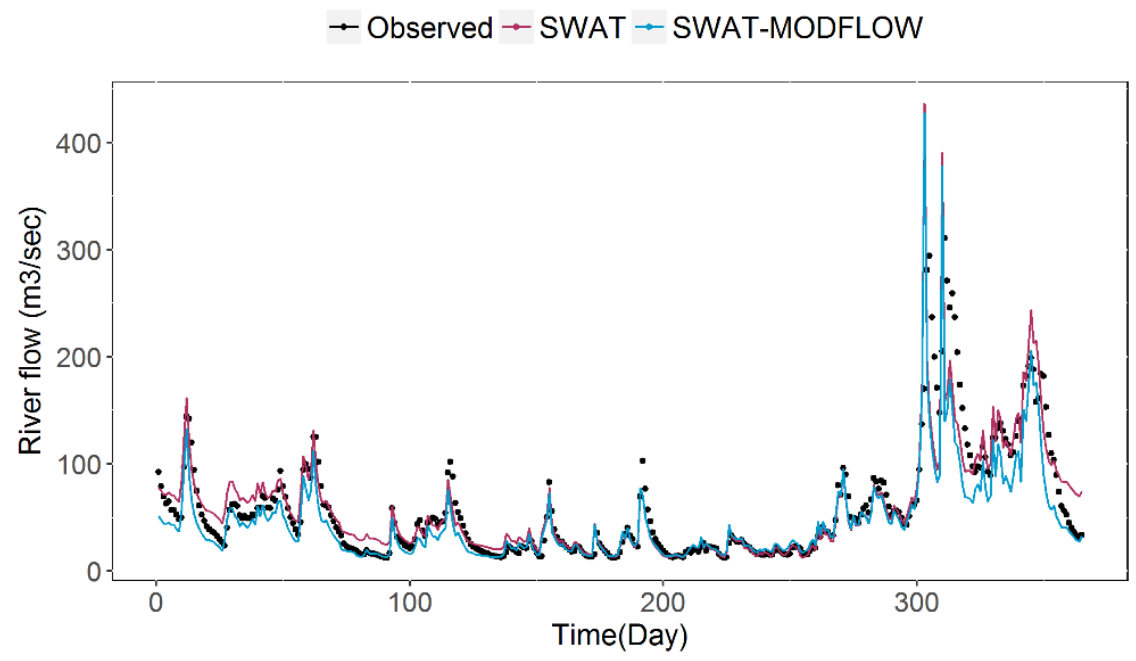

Figure 4: The comparison of simulated river flow from the standalone SWAT model and the coupled SWAT-MODFLOW at Iron Bridge for water year of 1999

The simulations from the standalone SWAT model and the coupled model are compared with the observed flow data at the river gauges. Figure 4 shows such comparison for one station (Chester Ironbridge) over the water year 1999. A remarkable feature revealed by Fig. 4 is that the coupled model clearly outperforms the standalone SWAT model for the low flow (i.e. baseflow) conditions, particularly for the recession curve of each peak. While both models simulate peak flow well, the standalone SWAT model performs better during the $2^{\text {nd }}$ peak. It is plausible that the MODFLOW component has well compensated the deficiency of SWAT in low flow representation (such as baseflow) in terms of taking more water the recharge. This is in fact an important aspect of the coupled model, as it is more stressful in the flow period for water supply and the coupled model may be preferred in this occasion for better simulations. 
Improving River Flow Simulation Using a Coupled Surface-Groundwater Model for ... S. Abbas et al.

\begin{tabular}{l|c|c|c|c}
\hline \multirow{2}{*}{ Station } & \multicolumn{2}{|c|}{ SWAT } & \multicolumn{2}{c}{ SWAT-MODFLOW } \\
\cline { 2 - 5 } & NSE & $\mathbf{R}^{\mathbf{2}}$ & NSE & $\mathbf{R}^{\mathbf{2}}$ \\
\hline Manley Hall & 0.76 & 0.90 & 0.88 & 0.96 \\
\hline Chester & 0.70 & 0.86 & 0.83 & 0.95 \\
\hline Suspension & 0.56 & 0.79 & 0.98 & 0.91 \\
\hline Pont-y-Capel & 0.57 & 0.87 & 0.67 & 0.85 \\
\hline Bowling Bank & -0.42 & 0.86 & 0.77 & 0.85 \\
\hline Brynkinalt Weir & 0.82 & 0.89 & 0.27 & 0.87 \\
\hline
\end{tabular}

Table 2: The calibrated baseflow results of the standalone SWAT model and the coupled SWATMODFLOW model for the period of 1995-2000

We also consider a baseflow simulation of the standalone SWAT and coupled SWATMODFLOW. The NSE and $\mathrm{R}^{2}$ are employed to evaluate observed and simulated baseflow. Table 2 shows that the SWAT-MODFLOW simulation has a better baseflow simulation than the original SWAT model. Figure 5 reveals the baseflow of SWAT, SWAT-MODFLOW and the observed flow at Pont-y-Capel station for the period of 1995-2000. Noticeably, SWAT-MODFLOW improves the original SWAT simulation regarding baseflow. Figure 6 shows the comparison of daily simulated and observed groundwater levels at the monitoring well in the east of Dee watershed, showing that the coupled SWAT-MODFLOW also performs well in simulating groundwater levels $\left(\mathrm{R}^{2}\right.$ of 0.87 for the period of 1995-2000).

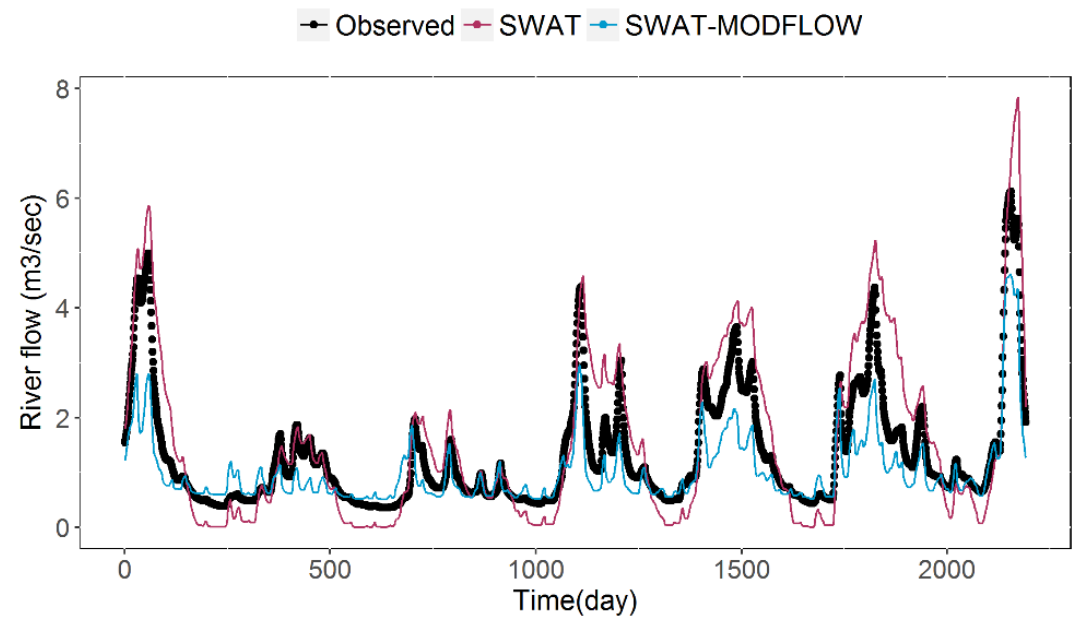

Figure 5: The comparison of simulated baseflow from the standalone SWAT model and the coupled SWATMODFLOW at Pont-y-Capel for the period of 1995-2000 


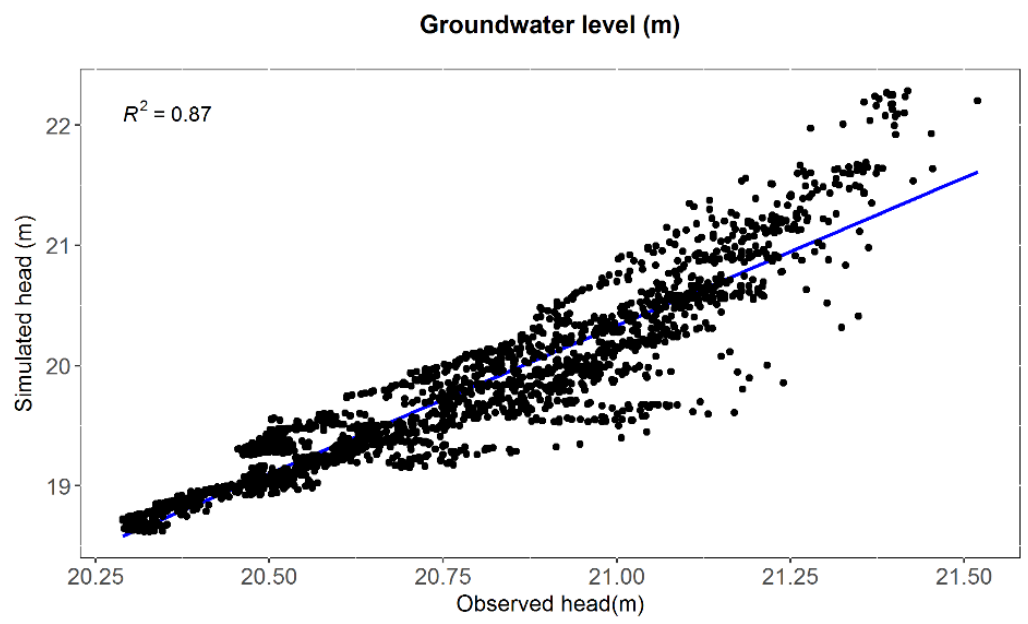

Figure 6: The comparison of simulated groundwater level from the coupled SWAT-MODFLOW at the monitoring well for the period of 1995-2000

\section{Conclusion}

We demonstrate a study using the coupled SWAT-MODFLOW to simulate the hydrological processes in a complex catchment in the United Kingdom. Preliminary results show that the coupled model can produce comparably better simulations of low flows in the stream network, and thereby improved the water balance in the catchment. Further work with the model will include additional calibration to improve stream flow and also groundwater level fluctuations. Overall, the study shows a promising direction of using coupled surface-groundwater model in IWRM.

\section{Acknowledgement}

The authors wish to thank Natural Resources Wales, Met Office and British Geological Survey for providing necessary data used by this study. The first author is also supported by the scholarship provide by Higher Committee for Education Development in Iraq (HCED) which is also kindly acknowledged.

\section{References}

[1]Arnold, J., Srinivasan, R., Muttiah, R., \& Williams, J. Large area hydrologic modeling and assessment part I: model development. JAWRA Journal of the American Water Resources Association 34.1 (1998): 73-89.

[2] Niswonger, Richard G., Sorab Panday, and Motomu Ibaraki. MODFLOW-NWT, a Newton formulation for MODFLOW-2005. No. 6-A37. US Geological Survey, (2011).

[3] Golmohammadi, G., Rudra, R., Dickinson, T., Goel, P., \& Veliz, M. Predicting the temporal variation of flow contributing areas using SWAT. Journal of Hydrology 547 (2017): 375-386. 
Improving River Flow Simulation Using a Coupled Surface-Groundwater Model for ... S. Abbas et al.

[4] Milzow, Christian, and Wolfgang Kinzelbach. Accounting for subgrid scale topographic variations in flood propagation modeling using MODFLOW. Water Resources Research 46.10 (2010).

[5] Bailey, R., et al. "Assessing regional - scale spatio - temporal patterns of groundwater-surface water interactions using a coupled SWAT - MODFLOW model." Hydrological Processes 30.23 (2016): 4420-4433.

[6] Bailey, R., et al. "SWATMOD - Prep: Graphical User Interface for Preparing Coupled SWAT - MODFLOW Simulations." JAWRA Journal of the American Water Resources Association 53.2 (2017): 400-410.

[7] Eckhardt, K. "A Comparison of Baseflow Indices, Which Were Calculated with Seven Different Baseflow Separation Methods". Journal of Hydrology 352, no. 1-2 (2008): 168-173.

[8] Tallaksen, L. "A Review of Baseflow Recession Analysis". Journal of Hydrology 165, no. 1-4 (1995): 349-370.

[9] Luo, Y., J. Arnold, P. Allen, and X. Chen. "Baseflow Simulation Using SWAT Model in an Inland River Basin in Tianshan Mountains, Northwest China". Hydrology and Earth System Sciences 16, no. 4 (2012): 1259-1267.

[10] Arnold, Jeffrey G., Peter M. Allen, and Gilbert Bernhardt. "A Comprehensive SurfaceGroundwater Flow Model". Journal of Hydrology 142, no. 1-4 (1993): 47-69.

[11] Srivastava, Puneet, James N. McNair, and Thomas E. Johnson. "Comparison of processbased and artificial neural network approaches for streamflow modeling in an agricultural watershed". Journal of the American Water Resources Association 42, no. 3 (2006): 545-563.

[12] Chu, T. W., and Shirmohammadi, A. "Evaluation of the swat model's hydrology component in the piedmont physiographic region of Maryland". Transactions of the ASAE 47, no. 4 (2004): 1057-1073.

[13] Wu, Kangsheng, and Carol A. Johnston. "Hydrologic Response to Climatic Variability in A Great Lakes Watershed: A Case Study with The SWAT Model". Journal of Hydrology 337, no. 1-2 (2007): 187-199.

[14] Kim, Nam Won, Il Moon Chung, Yoo Seung Won, and Jeffrey G. Arnold. "Development and Application of the Integrated SWAT-MODFLOW Model". Journal of Hydrology 356, no. 1-2 (2008): $1-16$.

[15] Guzman, J.A., D.N. Moriasi, P.H. Gowda, J.L. Steiner, P.J. Starks, J.G. Arnold, and R. Srinivasan. "A Model Integration Framework for Linking SWAT and MODFLOW". Environmental Modelling \& Software 73 (2015): 103-116.

[16] Gassman, P. W. , Reyes M. R., Green, C. H., and J. G. Arnold. "The Soil And Water Assessment Tool: Historical Development, Applications, And Future Research Directions". Transactions of the ASABE 50, no. 4 (2007): 1211-1250.

[17] Lyne, V. D., and M. Hollick. "Stochastic Time-Variable Rainfall-Runoff Modelling". In. Perth, Australia: Hydrology and Water Resources Symposium, 1979.

[18] Nathan, R. J., and T. A. McMahon. "Evaluation of Automated Techniques for Base Flow and Recession Analyses". Water Resources Research 26, no. 7 (1990): 1465-1473.

[19] Fuka DR, Walter MT, Archibald JA, Steenhuis TS, Easton ZM, Fuka MD, KeepSource TR. Package 'EcoHydRology'. 